\title{
SEASONAL CONTRIBUTION OF LIVING PHYTOPLANKTON CARBON TO \\ VERTICAL FLUXES IN A COASTAL UPWELLING SYSTEM \\ (RÍA DE VIGO, NW SPAIN)
}

Zúñiga, D. ${ }^{1}$, Alonso-Pérez, F. ${ }^{1}$, Castro, C.G. ${ }^{1}$, Arbones, B. ${ }^{1}$, Figueiras, F.G. ${ }^{1}$

${ }^{1}$ Instituto de Investigacións Mariñas (IIM), CSIC, Vigo, Spain. 


\section{ABSTRACT}

The aim of this study is to explore the contribution of living phytoplankton carbon to vertical fluxes in a coastal upwelling system as a key piece to understand the coupling between primary production in the photic layer and the transfer mechanisms of the organic material from the photic zone. Between April 2004 and January 2005, five campaigns were carried out in the Ría de Vigo (NW Iberian Peninsula) covering the most representative oceanographic conditions for this region. Measurements of particulate organic carbon (POC), chlorophyll-a (chl a), phaeopigments (phaeo), and identification of phytoplankton species were performed on the water column samples and on the organic material collected in sediment traps.

The POC fluxes measured by the sediment traps presented no seasonal variation along the studied period ranging around a mean annual value of 1085 $\pm 365 \mathrm{mg} \mathrm{m}^{-2} \mathrm{~d}^{-1}$, in the upper range of previously reported values for other coastal systems. The fact that higher POC fluxes were registered during autumn and winter, when primary production rates were at their minimum levels points to a dominant contribution of organic carbon from resuspended sediments on the trap collected material. On the contrary, fluxes of living phytoplankton carbon $\left(\mathrm{C}_{\text {phyto }}\right)$ and chl a clearly presented a seasonal trend with maximum values during summer upwelling $\left(546 \mathrm{mg} \mathrm{m}^{-2} \mathrm{~d}^{-1}\right.$ and $22 \mathrm{mg} \mathrm{chl} \mathrm{a} \mathrm{m}^{-2}$ $\left.\mathrm{d}^{-1}\right)$ and minimum values during winter $\left(22 \mathrm{mg} \mathrm{m}^{-2} \mathrm{~d}^{-1}\right.$ and $\left.0.1 \mathrm{mg} \mathrm{chl} \mathrm{a} \mathrm{m}^{-2} \mathrm{~d}^{-1}\right)$. The contribution of $\mathrm{C}_{\text {phyto }}$ to the vertical flux of POC ranged between $2 \%$ and $49 \%$ in response to the pelagic phytoplankton community structure. Higher values of $\mathrm{C}_{\text {phyto }}$ fluxes were registered under upwelling conditions which favour 
the dominance of large chain-forming diatoms (Asterionellopsis glacialis and Detonula pumila) that were rapidly transferred to the sediments. By contrast, $\mathrm{C}_{\text {phyto }}$ fluxes decreased during the summer stratification associated with a pelagic phytoplankton community dominated by single cell diatoms and flagellates. Minimal $\mathrm{C}_{\text {phyto }}$ fluxes were observed during the winter mixing conditions, when the presence of the benthic specie Paralia sulcata in the water column also points toward strong sediment resuspension.

Keywords: sediment traps, organic carbon fluxes, phytoplankton assemblages, diatoms

\section{INTRODUCTION}

The phytoplankton community structure plays a fundamental role in the variability of the biological production in marine ecosystems. This is of especial relevance since quantifying the amount of organic carbon resulting from phytoplankton production and sinking below the photic zone is a powerful tool revealing the major pathways of carbon flowing through the ecosystem (Wassmann et al., 2003; Boyd and Trull, 2007; Reigstad et al., 2008) and otherwise is of great importance in determining the oceanic sequestration of anthropogenic $\mathrm{CO}_{2}$ (Eppley and Peterson, 1979).

Unravelling the mechanisms that control the removal of suspended particulate organic carbon from the photic zone is critical to understand the vertical flux regulation and its effect on the benthic - pelagic coupling. There is an emerging evidence of the importance of ecosystem functioning on the vertical export of 
organic carbon (Wassmann et al., 2003; Boyd and Trull, 2007). The retention capacity of the pelagic system determines the quantity and quality of the vertical flux of organic matter as it has been extensively reported (Pakhomov et al., 2002; Tamelander and Heiskanen, 2004; Herrera and Escribano, 2006; Hargrave et al., 2007; Svensen et al., 2007; Pommier et al., 2008; Sanchez et al., 2008). An efficient pelagic food web reduces the quantity and quality of organic material exported, while moderate pelagic consumption of fixed carbon favours the vertical export of organic matter (Reigstad et al., 2008).

Despite the fact that the NW lberian coast is the most important upwelling region in Europe, there are very few studies focused on the vertical sinking of organic material (Bode et al., 1998; Olli et al., 2001; Varela et al., 2004) and none of them cover an entire year. Olli et al. (2001) described how the activity of biological, physical and biogeochemical processes together with the composition and structure of the pelagic communities determine the magnitude of vertical flux. Besides, Bode et al. (1998) and Varela et al. (2004) showed how the phytoplankton living cells are contributing to sedimented carbon in two different sites, off La Coruña and in the Ría de Pontevedra, respectively.

The aim of our study is to describe the seasonal pattern of vertical export of particulate organic matter from the photic zone and to explore to what extent the phytoplankton community structure modulates this export in the Ría de Vigo. The fact of jointly considering data from water column samples and those obtained with sediment traps will allow us to better understand the coupling between primary production in the photic layer and the transfer mechanisms of the organic material to deeper waters. To our knowledge, this study is the first 
to cover an entire year of sediment trap data for the NW Iberian coastal upwelling region.

\section{MATERIAL AND METHODS.}

\subsection{Study area}

The Ría de Vigo is one of the four V-shaped Rías Baixas embayments. As the other Rías Baixas, it gradually widens seawards and it is partially enclosed by the Cíes Islands (Figure 1). It reaches a maximum depth of $55 \mathrm{~m}$ along its central channel. Its main tributary is the Oitabén-Verdugo River which drains into the innermost part of the Ría with an average flow of $15 \mathrm{~m}^{3} \mathrm{~s}^{-1}$ (Nogueira et al., 1997).

From May to October, the Rías Baixas are strongly influenced by prevailing northerly winds that cause the upwelling of subsurface Eastern North Atlantic Central Water (ENACW) on the shelf and into the Rías. These upwelling events reinforce positive estuarine circulation inside the Rías, favouring the surface outflow of freshwater and the subsurface inflow of cold nutrient-rich ENACW. On the contrary, during winter, the Rías are characterized by a negative circulation.

The annual cycle of primary production in the Rías is mainly controlled by hydrodynamic forcing. From late spring to September-October the occurrence of upwelling events increases primary production (Fraga, 1981) and consequently, the export of biogenic particles to the sediment and adjacent slope (Alvarez-Salgado et al., 2001). From October to March when prevailing southerly winds favour downwelling processes and water column mixing the primary production is reduced due to light limitation. Previous studies (Tilstone 
et al., 1999; Cermeño et al., 2006; Arbones et al., 2008) presented high values of total primary production during upwelling season, ranging from $1120 \mathrm{mg} \mathrm{C} \mathrm{m}^{-}$ ${ }^{2} \mathrm{~d}^{-1}$ to $8751 \mathrm{mg} \mathrm{C} \mathrm{m}^{-2} \mathrm{~d}^{-1}$, and low values, of around $60-65 \mathrm{mg} \mathrm{C} \mathrm{m}^{-2} \mathrm{~d}^{-1}$ during winter.

\subsection{Sampling strategy and water column analytical methods.}

In the framework of the Spanish project FLUVBE (Acoplamiento de los flujos verticales y bentónicos), 16 oceanographic cruises were carried out at station $I R$, located in the inner part of Ría de Vigo (Figure 1). The cruises covered the period between April 2004 and January 2005 and the sampling strategy tried to capture the main oceanographic conditions for the study area; i.e. spring bloom (April), summer upwelling-stratification (July), autumn bloom (October) and winter mixing (January). During each period, the station was visited twice a week during a 15 days period. Additionally, another sampling site in the outer part of the Ría de Vigo (OU station; Figure 1) was monitored 4 times from July 19 to July 29 (2004) in the framework of european project MABENE.

Ekman transport $\left(-Q_{x}\right)$, an estimate of the volume of water upwelled per kilometre of coast, was calculated according to Bakun's (1973) method:

$-Q_{x}=-\left(\left(\rho_{a} C|V|\right) /\left(f \rho_{s w}\right)\right) V_{H}$

where $\rho_{\mathrm{a}}$ is the density of the air $\left(1.22 \mathrm{~kg} \mathrm{~m}^{-3}\right)$ at $15{ }^{\circ} \mathrm{C}, \mathrm{C}$ is an empirical dimensionless drag coefficient $\left(1.410^{-3}\right), f$ is the Coriolis parameter $\left(9.94610^{-5}\right)$ at $43^{\circ} \mathrm{N}, \rho_{\mathrm{sw}}$ is the seawater density $\left(1025 \mathrm{~kg} \mathrm{~m}^{-3}\right)$ and $|\mathrm{V}|$ and $\mathrm{V}_{\mathrm{H}}$ are the average daily module and northerly component of the geostrophic winds centred at $43^{\circ} \mathrm{N}, 11^{\circ} \mathrm{W}$, respectively. Average daily winds were estimated from atmospheric pressure charts. Positive values of $-Q_{x}$ showed the predominance 
of northerly winds that induce upwelling inside the Ría. In contrast, negative values indicate the existence of downwelling processes.

At each station, vertical profiles of temperature, salinity, photosynthetic active radiation (PAR), transmittance and fluorescence were obtained with a Seabird CTD probe with a Seatech fluorometer. Discrete water samples at nominal depths $(5,10,15,20 \mathrm{~m}$ depth) were collected by means of a rosette sampler with 10-L PVC Niskin bottles for determination of nitrate concentration, particulate organic carbon and nitrogen (POC and PON) concentration, chlorophyll-a (chl a), phaeopigments (phaeo) and samples for microplankton counting.

Nitrate was determined by segmented flow analysis with Alpkem autoanalyzers (Hansen and Grasshoff, 1983). The analytical error was $\pm 0.05 \mu \mathrm{M}$. For POC and PON analysis, $250 \mathrm{~mL}$ samples were filtered on pre-weighted, precombusted Whatman GF/F filters (0.7 $\mu \mathrm{m}$ nominal size pore), dried overnight and frozen $\left(-20^{\circ} \mathrm{C}\right)$ before analysis. Measurements of POC and PON were carried out with a Perkin Elmer $2400 \mathrm{CNH}$ analyser, including daily acetanilide standards. The precision of the method is $\pm 0.3 \mu \mathrm{mol} \mathrm{C} \mathrm{L} \mathrm{L}^{-1}$ and $\pm 0.1 \mu \mathrm{mol} \mathrm{N} \mathrm{L}{ }^{-1}$. Total chl $a$ and phaeo were analyzed by filtering 100 to $250 \mathrm{~mL}$ seawater samples through Whatman GF/F filters $(0.7 \mu \mathrm{m}$ of size pore). After filtration, samples were frozen $\left(-20^{\circ} \mathrm{C}\right)$ until pigment extraction in $90 \%$ acetone over $24 \mathrm{~h}$ in the dark at $4^{\circ} \mathrm{C}$. Final concentrations were determined by pigment extract fluorescence using a Turner Designs fluorometer calibrated with pure chl a (Sigma).

Measurements of net community production (NCP) and dark community respiration (DCR) were determined by $24 \mathrm{~h}$ in situ light-dark bottle oxygen 
incubations at 5 depths. Oxygen was determined by an automated Winkler titration system. Net in vitro changes in the light and dark bottles gave NCP and DCR, respectively. For further details see Arbones et al. (2008).

Samples for microplankton counting were collected at four nominal depths in the water column $(5,10,15,20 \mathrm{~m}$ depth). A seawater volume of $100 \mathrm{~mL}$ was preserved with Lugol's iodine until microcoscopic determination. Depending on the chl a concentration, a volume ranging from 10 to $50 \mathrm{~mL}$ was sedimented in composite sedimentation chambers and observed through an inverted microscope. The phytoplankton organisms were counted and identified to the species level. Dimensions were taken to calculate cell biovolumes after approximation to the nearest geometrical shape (Hillebrand et al., 1999) and cell carbon was calculated following Strathmann (1967) for diatoms and dinoflagellates, Verity et al. (1992) for other flagellates (> $20 \mu \mathrm{m})$ and Putt and Stoecker (1989) for ciliates. Although not properly estimated with this methodology, picophytoplankton constitutes a very small fraction $(<6 \%)$ of total phytoplankton in the Ría de Vigo (Arbones et al., 2008).

It is important to study phytoplankton populations both in terms of cell number and cell volume due to the fact that studies based on cell number give relative importance to the smaller species, whereas studies based on cell volume assume much greater importance of larger forms.

\subsection{Sediment traps}

Vertical particle fluxes were measured using a multitrap collector (MC) system. It was composed by 4 baffled cylinders of $6 \mathrm{~cm}$ diameter and a height/diameter ratio of 10.8. They were deployed for 24 hours in both stations at $\sim 4 \mathrm{~m}$ above 
bottom without the addition of any preservatives (filled with brine solution). Samples for chl a, phaeo and POC and PON analyses were obtained by filtering $200 \mathrm{~mL}$ onto pre-weighted, pre-combusted (450ㅇ, $4 \mathrm{~h})$ Whatman $\mathrm{GF} / \mathrm{F}$ filters (0.7 $\mu \mathrm{m}$ nominal pore size). POC analyses were carried out over decarbonated samples (using $\mathrm{HCl}$ vapours) with a Perkin Elmer $2400 \mathrm{CNH}$ analyser as described above for the water column samples. A fraction of 100 $\mathrm{mL}$ preserved in Lugol's iodine was employed for microplankton determination. Unfortunately, we do not have data of chlorophyll and phytoplankton carbon fluxes for the spring cruise.

Regarding trap collection efficiency, it is well known that some biases might affect sediment traps moored in the upper water column. In this sense, Baker et al. (1988) established that for speeds $<12 \mathrm{~cm} \mathrm{~s}^{-1}$ mass flux collected from moored sediment traps was indistinguishable from that collected in drifting traps, which are considered to be free of hydrodynamic biases. Our current meters mounted at the trap mouth registered water current velocities lower than $12 \mathrm{~cm} \mathrm{~s}^{-1}$ for $90 \%$ (de la Granda, pers. comm.) of the time they were deployed. Therefore, we assume that hydrodynamical biases affecting the sediment traps can be considered negligible.

\section{RESULTS}

3.1. Hydrographic and biogeochemical characteristics of the water column Temporal variations of the hydrodynamic conditions (Ekman transport, temperature) and the biogeochemical characteristics (nitrate, chl a and POC concentrations) of the water column are presented in Figure 2 and Figure 3, respectively. In spring, we found a transition from downwelling to upwelling 
conditions as observed by $-Q_{x}$ values, from negative to positive values. When downwelling occurred, low nitrate concentrations $\left(<1 \mu \mathrm{mol} \mathrm{kg}^{-1}\right)$ and chl a $(\sim 3-$ $5 \mathrm{mg} \mathrm{m}^{-3}$ ) were observed. From April $26^{\text {th }}$ onwards, when cold upwelled water entered into the Ría, nitrate concentration increased up to $7 \mu \mathrm{mol} \mathrm{kg}{ }^{-1}$ and a subsurface chl a $\left(7 \mathrm{mg} \mathrm{m}^{-3}\right)$ maximum was recorded, in agreement with relatively high POC concentration $\left(240 \mathrm{mg} \mathrm{m}^{-3}\right.$ ). During the first two weeks of July, a succession of upwelling-relaxation cycles, as indicated by temporal variability of $-Q_{x}$, provoked the upwelling of cold and nutrient-rich subsurface waters into the Ría. These oceanographic conditions favoured the development of chl a $\left(14 \mathrm{mg} \mathrm{m}^{-3}\right)$ and POC $\left(480 \mathrm{mg} \mathrm{m}^{-3}\right)$ maxima at the thermocline level. In contrast, the second half of July was characterized by an intense water column stratification $\left(-Q_{x}\right.$ remains close to zero; temperature ranges from $13^{\circ} \mathrm{C}$ at the bottom to $19^{\circ} \mathrm{C}$ at the surface) inducing a decreasing in nitrate $\left(1-3 \mu \mathrm{mol} \mathrm{kg}{ }^{-1}\right)$, chl a (1-3 $\left.\mathrm{mg} \mathrm{m}^{-3}\right)$ and POC (120-180 $\left.\mathrm{mg} \mathrm{m}^{-3}\right)$ levels. During autumn, we firstly found strong upwelling conditions $\left(-Q_{x}\right.$ reached a value as high as $2100 \mathrm{~m}^{3} \mathrm{~s}^{-1}$ $\mathrm{Km}^{-1}$ ) with high nitrate concentration (up to $7 \mu \mathrm{mol} \mathrm{kg}^{-1}$ ) and a chl a maximum (7-9 $\mathrm{mg} \mathrm{m}^{-3}$ ) close to the bottom. In the second half of the period, the water column was homogenized showing a constant temperature of $15^{\circ} \mathrm{C}$ with low nitrate $\left(<3 \mu \mathrm{mol} \mathrm{kg}^{-1}\right)$, chl a $\left(<2 \mathrm{mg} \mathrm{m}^{-3}\right)$ and POC $\left(<120 \mathrm{mg} \mathrm{m}^{-3}\right)$ levels for the whole water column. Finally, during winter the water column was strongly mixed

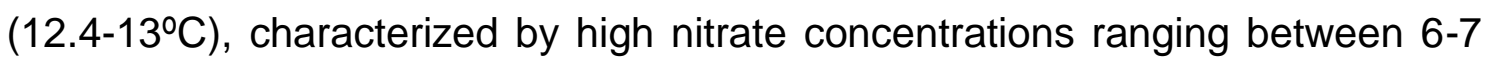
$\mu \mathrm{mol} \mathrm{kg}{ }^{-1}$ and low chl $a$ and POC contents, remaining below than $1 \mathrm{mg} \mathrm{m}^{-3}$ and $150 \mathrm{mg} \mathrm{m}^{-3}$, respectively.

\subsection{Phytoplankton community in the water column}


During the spring downwelling days, the low content of chl a agreed with the relatively low phytoplankton biomass (Figure 3). Both diatoms $(40 \% \pm 24)$ and flagellates $(50 \% \pm 23)$ were predominant during that time (Figure 4 and Table 1). This pattern was also shown in Figure 6 where it is reflected that small flagellates jointly with diatoms from the Chaetoceros genus are the most representative phytoplankton cells in the water column, both in terms of abundance and phytoplanktonic biomass. During the second half of the cruise, upwelling conditions favoured the development of a subsurface chl a maximum, associated with the highest abundance $\left(150010^{6} \mathrm{cel} \mathrm{m}^{-3}\right)$ and biomass $(300 \mathrm{mg}$ $\mathrm{C} \mathrm{m}^{-3}$ ) of phytoplankton for this period (Figure 3). This maximum was mainly explained by the diatoms group where values as high as $80 \%$ were recorded (Figure 4 ). High-size diatom specie Detonula pumila was the major contributor to this maximum both in terms of abundance of cells and biomass of phytoplankton carbon (Figure 6).

During the summer upwelling, the maximum of $\mathrm{chl} a\left(14 \mathrm{mg} \mathrm{m}^{-3}\right)$ at subsurface waters was clearly associated with the highest abundance $\left(250010^{6} \mathrm{cel} \mathrm{\textrm {m } ^ { - 3 }}\right)$ and biomass (450 $\mathrm{mg} \mathrm{C} \mathrm{m}^{-3}$ ) of phytoplankton (Figure 3). The phytoplankton community was clearly dominated by diatoms (Figure 4) during the whole period with high abundances of diatoms that frequently appear forming colonies (Pseudo-nitzschia delicatissima, Asterionellopsis glacialis, Detonula pumila and Leptocylindrus danicus) (Figure 6a). These species also represented the major percentage of phytoplankton biomass (Figure 6b).

During the second half of July, when stratification of the water column occurred, a decrease in both chl $a$ and phytoplankton biomass $\left(25-100 \mathrm{mg} \mathrm{C} \mathrm{m}^{-3}\right.$ ) (Figure 3) was observed. The chl a maxima, just below the thermocline for the 
first and last days of this period, agreed well with the relatively high values of both diatoms and dinoflagellates biomass (Figure 4 and Table 1). In terms of species, the most abundant phytoplanktonic cells were Chaetoceros sp., Leptocylindrus danicus and Detonula pumila (Figure 6a). The phytoplankton biomass was almost totally explained by the large-size diatoms Detonula pumila and Asterionellopsis glacialis (Figure 6b).

The contrasting water column structures between the first and last half of the autumn cruise, clearly marked the distributions of chl a, abundance and biomass of phytoplankton (Figure 3). The maximum of abundance (up to 800 $10^{6} \mathrm{cel} \mathrm{m}^{-3}$ ), associated to the diatom group (Figure 4), was mainly explained by Chaetoceros socialis (Figure 6a). In terms of biomass, this maximum (200 mg C $\mathrm{m}^{-3}$ ) was related to several diatom species (Stephanopyxis turris, Eucampia zoodiacus, small Chaetoceros spp.) and the dinoflagellate Ceratium furca (Figure 6b). On the contrary, the second part of the cruise, when water column was clearly mixed, was characterized by low contents of chl a reflected on the decrease of phytoplankton cells (Figure 3). In addition to phytoplankton biomass and abundance decrease, there was also a shift in phytoplankton composition (Figure 4 and Table 1). Remark the presence of large solitary cells of Coscinodiscus sp. and dinoflagellate Ceratium furca as the most important contributors to phytoplankton biomass (Figure 6b) during these last days of the autumn cruise.

Finally, during winter, there was an abrupt decrease in phytoplankton abundance $\left(15-3510^{6} \mathrm{cel} \mathrm{m}^{-3}\right)$ and biomass $\left(2-3 \mathrm{mg} \mathrm{C} \mathrm{m}^{-3}\right)$, due to strong water column mixing and light limitation (Figure 3). These very low values were mainly explained by the presence of small flagellates, the dinoflagellate Heterocapsa 
niei and single cell diatoms such as Pseudo-nitzschia and Cylindrotheca closterium (Figure 6).

\subsection{Sedimentation of chl a, particulate organic carbon and phytoplankton}

The time-series of chl a, POC and phytoplankton fluxes, based on the material collected on the sediment traps, are presented in Figure 5. As expected in a productive system like the Ría de Vigo, mean POC fluxes for each sampling period were high (Table 2), varying around an annual average of $1085 \pm 365 \mathrm{mg}$ $\mathrm{m}^{-2} \mathrm{~d}^{-1}$. In spite of the fact that POC fluxes remained relatively high throughout the year, short-term variations were observed. Values ranged between a minimum of $543 \mathrm{mg} \mathrm{m}^{-2} \mathrm{~d}^{-1}$, recorded after summer upwelling, and a maximum of $1928 \mathrm{mg} \mathrm{m}^{-2} \mathrm{~d}^{-1}$, registered during winter (Figure 5). Average $\mathrm{C} / \mathrm{N}$ ratios for the different periods remained below 7.5 , except for the winter period with an average $\mathrm{C} / \mathrm{N}$ ratio of $11.5 \pm 3.0$ (Table 2). As mentioned in the material and methods section, for the spring period we only obtained results of organic carbon and nitrogen and unfortunately we have no data of chl $a$ and $\mathrm{C}_{\text {phyto }}$ fluxes.

During the summer upwelling, the $\mathrm{C}_{\text {phyto }}$ fluxes increased with the entrance of subsurface nutrient rich waters in the Ría that favoured the rapid growth of phytoplankton cells (Figure 5). A maximum value of $546 \mathrm{mg} \mathrm{C} \mathrm{m}^{-2} \mathrm{~d}^{-1}$ was recorded associated with a chl a maximum in the traps $\left(22 \mathrm{mg} \mathrm{chl} \mathrm{a} \mathrm{m}^{-2} \mathrm{~d}^{-1}\right)$. This maximum is explained by the dominance of diatoms, both in terms of abundance (2438 $\left.10^{6} \mathrm{cel} \mathrm{m}^{-2} \mathrm{~d}^{-1}\right)$ and biomass $\left(546 \mathrm{mg} \mathrm{C} \mathrm{m}^{-2} \mathrm{~d}^{-1}\right)$ (Figure 5). Under the water column stratification conditions of the second half of July, $\mathrm{C}_{\text {phyto }}$ and chl a fluxes were smaller than during the previous upwelling conditions, 
with minimum values of $57 \mathrm{mg} \mathrm{C} \mathrm{m}^{-2} \mathrm{~d}^{-1}$ and $3.6 \mathrm{mg} \mathrm{chl} \mathrm{a} \mathrm{m}^{-2} \mathrm{~d}^{-1}$, respectively. In biomass terms, diatoms were the highest contributors, similarly to the summer upwelling period, but not in abundance terms where small flagellates were also important (Figures 5). During both summer upwelling and summer stratification sampling periods the most abundant diatom species were Pseudonitzschia delicatissima, Asterionellopsis glacialis and Detonula pumila (Figure 6a). However, only the large-size cells represented by Asterionellopsis glacialis and Detonula pumila explained a major percentage of the phytoplakton biomass recorded by the sediment traps (Figure 6b).

During autumn, there was a decrease of $\mathrm{C}_{\text {phyto }}$ flux from an initial relative maximum of $174 \mathrm{mg} \mathrm{m}^{-2} \mathrm{~d}^{-1}$ to a minimum of $54 \mathrm{mg} \mathrm{m}^{-2} \mathrm{~d}^{-1}$ at the end of the cruise. Concomitantly, there was a decrease in chl a fluxes from $12.6 \mathrm{mg} \mathrm{m}^{-2} \mathrm{~d}^{-1}$ to $2.4 \mathrm{mg} \mathrm{m}^{-2} \mathrm{~d}^{-1}$ (Figure 5). These trends in export fluxes were associated with the dramatic shift in oceanographic conditions for this cruise. $\mathrm{C}_{\text {phyto }}$ fluxes at the beginning of this period were related to upwelling conditions that induced the development of small Chaetoceros sp. diatoms $\left(517510^{6} \mathrm{cel} \mathrm{m}^{-2} \mathrm{~d}^{-1}\right)$ (Figure 5 and 6a). The shift to intense water column mixing for the last two cruise days provoked the disappearance of these small diatoms being remarkable the dominance of large Coscinodiscus as the major contributor to phytoplankton biomass (Figure 6b).

During winter, minimum values of $\mathrm{chl} a$ and $\mathrm{C}_{\text {phyto }}$ fluxes were recorded with averages of $0.8 \pm 0.6 \mathrm{mg} \mathrm{m}^{-2} \mathrm{~d}^{-1}$ and $28 \pm 6 \mathrm{mg} \mathrm{m}^{-2} \mathrm{~d}^{-1}$, respectively (Figure 5 and Table 2). The most abundant species of diatoms were small centric Pseudo-nitzschia cf. and Cylindrotheca closterium that frequently appear as individual cells (Figure 6a). In terms of biomass, these two species, alongside 
the large diatom Coscinodiscus sp. and the large dinoflagellate Pyrocystis lunula represented the major contributors to phytoplankton carbon (Figure 6b).

\section{DISCUSSION}

4.1. Seasonal pattern of vertical organic carbon fluxes in the Ría de Vigo.

In coastal upwelling regions, studies have quantitatively described the coupling between production, export and burial of particulate organic carbon (Wassmann, 1991; Fernández et al., 1995; Pilskaln et al., 1996; Wassmann et al., 1996; Thunell, 1998; Reigstad et al., 2008), fact that will contribute to understand the supply of energy to the benthic environments (Alonso-Pérez et al., 2010) and the mechanisms controlling ocean carbon cycle. In these terms, the structure of the phytoplankton community in marine ecosystems is of special relevance since it may affect both productivity and organic carbon fluxes (Passow and Peinert, 1993). Until now, most studies have described the phytoplankton assemblages in the water column or in the sediment traps but none of those studies have tried to simultaneously study the seasonal link between the standing stock of the phytoplankton community in the water column and its contribution to vertical export of organic carbon fluxes.

In spite of the key role of vertical export of organic matter from the photic zone, direct measurements of this export for the NW Iberian coastal upwelling system are scarce and the few published studies are based on short field campaigns (Bode et al., 1998; Olli et al., 2001; Varela et al., 2004). In this context, our data represent the first study of sediment trap fluxes covering an entire annual cycle for the NW Iberian upwelling system. During our study, vertical carbon fluxes varied between 543 to $1928 \mathrm{mg} \mathrm{m}^{-2} \mathrm{~d}^{-1}$, with an annual average of $1085 \pm 365$ 
$\mathrm{mg} \mathrm{m}^{-2} \mathrm{~d}^{-1}$ (Figure 5 and Table 2). These values are of the same order as those reported by Bode et al. (1998) for a coastal station off A Coruña (323 - 1203 $\mathrm{mg} \mathrm{m}^{-2} \mathrm{~d}^{-1}$ ) and by Varela et al. (2004) inside the Ria de Pontevedra (530 $1780 \mathrm{mg} \mathrm{m}^{-2} \mathrm{~d}^{-1}$ ) during prevailing upwelling conditions and relatively higher than values observed by Olli et al. (2001) from drifting sediment traps deployed on the continental shelf off the Rías Baixas $\left(60-240 \mathrm{mg} \mathrm{m}^{-2} \mathrm{~d}^{-1}\right)$ also during the upwelling season. These values from NE Atlantic upwelling region are in the upper range of previously reported values for other coastal upwelling systems as Chile (Gonzalez et al., 2007 and 2009), Benguela (Pitcher et al., 1991) and NW Africa (Head and Harris, 1994; Aristegui et al., 2004).

In contrast to the organic carbon fluxes, we did observe seasonal variability on the fluxes of phytoplankton carbon $\left(\mathrm{C}_{\text {phyto }}\right)$ during our study year. It varied from a seasonal average maximum of $260 \pm 219 \mathrm{mg} \mathrm{C} \mathrm{m}^{-2} \mathrm{~d}^{-1}$ for the summer upwelling to a seasonal average minimum of $28 \pm 6 \mathrm{mg} \mathrm{C} \mathrm{m}^{-2} \mathrm{~d}^{-1}$ for the winter campaign (Table 2). In this way, the average percentage of phytoplankton carbon flux over the total organic carbon varied from $26 \%$ during the summer upwelling to a minimum of $2 \%$ in winter. Our data range was similar to values presented by Olli et al. (2001), who showed a contribution of phytoplankton carbon to vertical particle flux of $18-29 \%$. Varela et al. (2004) also estimated a contribution of phytoplankton carbon ranging between $5-25 \%$ in the Ría de Pontevedra.

Similarly to the seasonal changes in phytoplankton carbon contribution, we also observed temporal changes of the $\mathrm{C} / \mathrm{N}, \mathrm{C}_{\text {phyto }} / \mathrm{chl} a$ and phaeo/chl $a$ ratios for the sediment trap material. These ratios changed from low values for the summer upwelling (6.8 $\pm 2.0,15 \pm 9$ and $1.7 \pm 0.6$, respectively; Table 2$)$ to high 
values for the winter conditions $(11.5 \pm 3.0,119 \pm 172$ and $7.0 \pm 5.5$, respectively), also pointing to a shift in the composition of the material collected on the traps. The low values for the upwelling period indicate the sinking of intact cells, while the high values for the winter period seem to point to an important contribution of resuspended sediment on the trap material. In fact, for this period the organic carbon fluxes were as high as the fluxes for the other periods, even though integrated primary production (Arbones et al., 2008) and zooplankton (Figueiras et al., 2009) were at their annual minimum, pointing to sediment resuspension as the possible source of the organic carbon. Additional evidence of the important role played by resuspension during winter, and also during the last week of October, is given by the vertical profiles of chlorophyllfluorescence and percentage of transmisttance for these periods (distributions not shown). In contrast with the summer cruises, during these periods we did not observe a significant correlation between these two variables (correlation coefficients of 0.45 and 0.28 for the autumn and winter cruises, respectively) related with the low percentages of transmittance at the bottom layer due to resuspension processes.

Thus, based on the trap data collected during our experimental year, the system seems to evolve from a scenario where there is a significant contribution of fresh phytoplankton carbon, as the upwelling conditions, towards a winter situation when the trap material is mainly of detrital origin. Besides, even though resuspension processes affected the sediment trap material during autumn and winter mixing conditions, we have obtained a strong relationship between the percentage of phytoplankton carbon over the total carbon for the traps and the equivalent percentage for the photic water column (correlation 
coefficient of $0.83 ; n=20$ ) and also a significant correlation between $\mathrm{C}_{\text {phyto }}$ flux and the photic zone integrated $\mathrm{chl}$ a (correlation coefficient of $0.78 ; n=20$ ), suggesting that the export of pelagic organic material from the photic zone is coupled to the water column phytoplankton community structure on annual basis.

\subsection{Phytoplankton contribution to the vertical export of organic carbon}

The phytoplankton composition of the water column in the Ría de Vigo follows a seasonal cycle (Figueiras and Ríos, 1993; Figueiras et al., 2002) characterized by the dominance of large diatoms (e.g. Thalassiosira rotula, Detonula pumila, Chaetoceros curvisetus) during the first spring upwelling events, when stratification of the water column is still incipient. In summer, with stronger stratification, small diatoms (e.g. Pseudo-nitzschia spp. and small Chaetoceros spp.) coexist with heterotrophic species of dinoflagellates (e.g. Protoperidinium spp, Gyrodinium spirale) and ciliates. Dinoflagellates, many of them potentially harmful, usually appear during the seasonal upwelling-downwelling transition at the end of summer. Benthic species (e.g. Paralia sulcata, Diploneis spp.) are often found in the water column in winter, when phytoplankton abundance is lower. This seasonal pattern is however disrupted by the sequence of upwelling events that frequently occur in summer, with the strongest events resetting the phytoplankton succession to early stages of the succession. Thus, large diatoms can be very abundant during summer upwelling.

The present study reveals that in this upwelling region there is also a seasonal variability on the contribution of phytoplankton carbon to the settling material out of the photic zone. In addition, our results indicate a seasonal variability in the 
settling phytoplankton assemblage, associated with the suspended phytoplankton community structure. Below, we discuss in what extent the magnitude and composition of the sinking phytoplankton assemblage reflects the structure of the phytoplankton community and consequently the water column metabolic balance, for the different periods except spring. As we mentioned before, sediment trap aliquots for phytoplankton counting were not available for the spring period.

During the summer upwelling period, phytoplankton carbon accounted for a large proportion of the carbon sinking flux and was mainly dominated by large diatoms (Figure 5 and 6). The composition of the settling phytoplankton assemblage was similar to the water column composition ( $92 \pm 6 \%$ and $94 \pm 3 \%$ of diatoms in terms of abundance and biomass respectively), contributing $74 \pm$ $24 \%$ of suspended POC (Table 1). The intense sinking of these ungrazed diatoms points to an imbalance between phytoplankton production and their pelagic utilisation by zooplankton. In fact, for this period high values of net community production $\left(406 \pm 99 \mathrm{mmol} \mathrm{O}_{2} \mathrm{~m}^{-2} \mathrm{~d}^{-1}\right)$ with dominance of phytoplankton cells $>20 \mu \mathrm{m}$, indicate a highly autotrophic pelagic community structure (Arbones et al., 2008). Thus, the situation responded to a nonretentive pelagic food web (Peinert et al., 1989) where fixed carbon is not used by pelagic herbivores and exported as intacted cells to the seabed. Such assumption was supported by the fact that large diatoms that frequently appear forming colonies were the most relevant species in biomass terms, both in the water column and in the sediment traps (Figure 6). The rapid sedimentation of these chain-forming diatoms has been related to coagulation efficiency and aggregate formation processes (Kiørboe and Hansen, 1993). 
During the summer stratification, the contribution of phytoplankton carbon to suspended POC was reduced to $29 \pm 16 \%$ (Table 1), showing that remineralization processes within the microbial food web had occurred and thus the export of organic matter from the photic zone had been reduced (Arbones et al., 2008). This explains why the phytoplankton carbon collected in the traps was lower than during the upwelling conditions (average $18 \pm 14 \%$; Table 2). On the other hand, even though the highest carbon contribution corresponded to the diatom group, there was also an important carbon contribution by dinoflagellates ( $16 \pm 8 \%$; Table 2 ). This phytoplankton carbon partition for the trap material was not too different from the pelagic phytoplankton assemblage, where dinoflagellates plus flagellates made up $23 \%$ of phytoplankton carbon. The important contribution of dinoflagellates in both traps and water column assemblages points to a retention chain for the fixed carbon in the pelagic zone (Peinert et al., 1989). According to these authors, under this carbon cycling pathway, fixed carbon in the pelagic zone is diverted by micro- and zooplankton grazing and a significant part of this carbon is sedimented as faecal pellet forms (Pilskan and Honjo, 1987). In fact, average net community production for this period was lower than for the summer upwelling situation (Table 1), suggesting a lower degree of autotrophy (Arbones et al., 2008). As it could be expected, the most abundant species in the water column were medium size diatoms (Figure 6a), frequently observed when water column is stratified (Casas et al., 1999; Varela et al., 2001; Civic et al., 2007). In spite of their high abundances in the water column, Chaetoceros curvisetus and Leptocylindrus danicus were practically absent in the trap material probably due to their morphological features. Chaetoceros curvisetus possesses long 
aerolated setae which facilitate buoyancy and the elongated cells of Leptocylindrus danicus large chains aid buoyancy in the water column (Margalef, 1978; Tilstone et al., 2000; Acuña et al., 2010). The highest contribution to phytoplankton carbon corresponded to large chain-forming diatoms (Detonula pumila and Asterionellopsis glacialis) as during the summer upwelling conditions though these diatom species were not the most abundant ones.

As previously mentioned, the autumn cruise registered a transition period from an upwelling event to a scenario of intense water column mixing (Figure 2). This shift in oceanographic conditions was also reflected on the metabolic balance of the water column (Table 1) and on the quality of the settling material composition (Table 2). During the first two days, when the system was clearly autotrophic $\left(\mathrm{NCP}=106 \mathrm{mmol} \mathrm{m}^{-2} \mathrm{~d}^{-1}\right)$ the contribution of phytoplankton carbon to the trap material reach a value as high as $18 \%$ (Table 2 ). On the contrary, during water column mixing conditions when low primary production rates were registered and the respiration rates were mainly controlled to heterotrophic processes (Table 1) (Arbones et al., 2008), the contribution of the living phytoplankton carbon to the trap material was reduced to a value as low as $4 \%$ (Table 2).In fact, the water column phytoplankton assemblage changed from a diatom-dominated assemblage for the upwelling conditions to an assemblage equally-partitioned by diatoms and dinoflagellates (Table 1). In contrast, for the trap material, there was a preferential sinking of diatoms, with a very similar diatom contribution for the entire autumn period (average biomass $83 \pm 15 \%$; Table 2). However, in the trap material we also did observe a species shift from a high contribution of Stephanopyxis turris and Eucampia zodiacus during the 
upwelling conditions, to a dominance of Coscinodiscus $s p$. during the mixing conditions. In fact, Coscinodiscus $s p$. is most favoured than the other large diatoms under mixing scenarios.

During the winter cruise, characterized by a well mixed water column with low temperatures and high nutrient levels (Figure 2), the phytoplankton carbon contribution in the sediment traps registered the minimum annual values (average $2.4 \pm 1.2 \%$ ) with diatoms as the main contributor group, both in terms of abundance and biomass (Table 2). The phytoplankton carbon in the water column also reached minimum values for this period, with a similar average in the sediment trap (average $2.4 \pm 0.8 \%$, Table 1 ) though with a very different phytoplankton composition (56 $\pm 30 \%$ and $55 \pm 15 \%$ of dinoflagellates plus flagellates in terms of biomass and abundance respectively). The active water column mixing caused the passive settling of non-sinking small diatoms on the sediment traps (Figure 6). On the other hand, as we discussed before this intense mixing induced a strong sediment resuspension which caused the appearance of the benthic diatom Paralia sulcata in the water column (Margalef, 1958, Casas et al., 1999, Civic et al., 2007).

\section{CONCLUSIONS}

The seasonal study of vertical export of organic matter in the Ría de Vigo (NW Iberian Peninsula) by considering the structure of the phytoplankton community reveals two main findings: (i) POC fluxes (annual average of $1085 \pm 365 \mathrm{mg} \mathrm{m}^{-2}$ $\mathrm{d}^{-1}$ ) are in the upper range of previously reported values for other coastal systems and do not show any seasonal trend; (ii) the contribution of $\mathrm{C}_{\text {phyto }}$ fluxes to the vertical export of organic material below the photic zone shows a 
clear seasonal pattern in response to the pelagic phytoplankton community structure. These values decrease from the summer upwelling (maximum value of $546 \mathrm{mg} \mathrm{m}^{-2} \mathrm{~d}^{-1}$ ) to the winter mixing period (minimum value of $22 \mathrm{mg} \mathrm{m}^{-2} \mathrm{~d}^{-1}$ ), accounting for between $49 \%$ and $2 \%$ of the total particulate organic carbon flux respectively. In spite of the fact that large diatoms were the most important contributor to $\mathrm{C}_{\text {phyto }}(79-96 \%)$ fluxes at all seasons, some variations in the settling phytoplankton assemblages have been observed for our experimental year. During the spring-summer period, when upwelling of cold nutrient-rich ENACW occurs, the phytoplankton community is dominated by large diatoms that have a high sinking capability. Afterwards, in summer when the water column reaches a strong stratification and nutrient levels are almost depleted, the system progresses to a suspended flagellate and small-diatom community at much lower biomass levels. Such conditions enhance the existence of remineralization processes within the microbial food web and decrease the vertical export of fixed carbon in the photic zone.

Finally, during winter, the intense mixing of the water column and the light limitation clearly caused a strong decrease of the water column phytoplankton carbon, mainly composed by small single-cell diatoms and dinoflagellates. In consequence, the $\mathrm{C}_{\text {phyto }}$ fluxes decreased though the organic carbon collected on the traps was still high due to the resuspension processes favoured by the intense vertical mixing.

In summary, the vertical sinking of phytoplankton carbon from the photic zone is controlled not only by primary production rates but also by the phytoplankton community structure. The size and the life-form of the different species of 
phytoplankton cells will control their capability to sink and play a key role in the particulate organic carbon cycle in this coastal upwelling system.

\section{ACKNOWLEDGEMENTS}

The authors thank the crew of the 'R/V Mytilus' and the members of the Department of Oceanography from the Instituto de Investigacións Mariñas de Vigo (CSIC) for their valuable help. Financial support came from CICYT project REN 2003-04458 and EU project EVK3-19 CT-2002-00071. D.Z. is funded by a postdoctoral fellowship(Jae-Doc) from the CSIC.

\section{REFERENCES}

Acuña, J.L., López-Alvarez, M., Nogueira, E., González-Taboada, F., 2010. Diatom flotation at the onset of the spring phytoplankton bloom: an in situ experiment. Mar. Ecol-Progr. Ser. 400: 115-125.

Alonso-Pérez, F., Ysebaert, T., Castro, C.G., 2010. Effects of suspended mussel culture on benthic-pelagic coupling in a coastal upwelling system (Ría de Vigo, NW Iberian Peninsula). J. Exp. Mar. Biol. Ecol. 382, 2: 96-107.

Álvarez-Salgado, X.A., Doval, M.D., Borges, A.V., Joint, I., Frankignoulle, M., Woodward, E.M.S., Figueiras, F.G., 2001. Off-shelf fluxes of labile materials by an upwelling filament in the NW Iberian Upwelling System. Prog. Oceanogr. 51: 321-337.

Arbones, B., Castro, C.G., Alonso-Pérez, F., Figueiras, F.G., 2008. Phytoplankton size structure and water column metabolic balance in a coastal upwelling system: the Ría de Vigo, NW Iberia. Aquat. Microb. Ecol. 50: 169179. 
Aristegui, J., Barton, E.D., Tett, P., Montero, M.F., García-Muñoz, M., Basterretxea, G., Cussatlegras, A.S., Ojeda, A., De Armas, D., 2004. Variability in plankton community structure, metabolism, and vertical carbon fluxes along an upwelling filament (Cape Juby, NW Africa). Prog. Oceanogr. 62: 95-113.

Baker, E.T., Milburn, H.B., Tennant, D.A., 1988. Field assessment of sediment trap efficiency under varying flow conditions. J. Mar. Res. 46, 573-592.

Bakun, A., 1973. Coastal upwelling Indices, West Coast of North America, 1946-71.

Bode, A., Varela, M., Barquero, S., Alvarez-Osorio, M.T., Gonzalez, N., 1998. Preliminary studies on the export of organic matter during phytoplankton blooms off La Coruña (Northwestern Spain). J. Mar. Biol. 78 (1): 1-15.

Boyd, P.W., Trull T.W., 2007. Understanding the export of biogenic particles in oceanic waters: Is there consensus? Prog. Oceanogr. 72(4): 276-312.

Casas, B., Varela, M., Bode, A., 1999. Seasonal succession of phytoplankton species on the coast of A Coruña (Galicia, Northwest Spain). Bol. Inst. Esp. Oceanogr. 15 (1-4): 413-429.

Cermeño P., Marañon, E., Pérez, V., Serret, P., Fernández, E., Castro, C.G., 2006. Phytoplankton size structure and primary production in a highly dynamic coastal ecosystem (Ría de Vigo, NW-Spain): Seasonal and short-term scale variability. Estuar. Coast. Shelf S. 67: 251-266.

Civic, T., Blasutto, O., Umani, S.F., 2007. Biodiversity of settled material in a sediment trap in the Gula of Trieste (northern Adriatic Sea). Hydrobiologia, 580: $57-75$

Eppey, R.W., Peterson, B.J., 1979. Particulate organic matter flux and planktonic new production in the deep ocean. Nature, 282: 456-477. 
Fernández, E., Marañón, E., Cabal, J., Alvarez, F., Anadón, R., 1995. Vertical particle flux in outer shelf waters of the southern Bay of Biscay in summer 1993. Oceanol. Acta, 18: 379-384.

Figueiras, F.G., Ríos, A.F., 1993. Phytoplankton succession, red tides and the hydrographic regime in the Rías Bajas of Galicia. In: Smayda, T.J., Shimizu, Y. (Eds.), Toxic phytoplankton blooms in the Sea. Elsevier, New York, pp. 239244.

Figueiras, F.G., Labarta, U., Fernández Reiriz, M.J., 2002. Coastal upwelling, primary production and mussel growth in the Rías Baixas of Galicia. Hydrobiologia 484: 121-131.

Figueiras, F.G., Miranda, A., Riveiro, I., Vergara, A.R., Guisande, C., 2009. El plancton de la Ría de Vigo. In: González-Garcés, A., Vilas, F., Álvarez-Salgado, X.A. (Eds.), La Ría de Vigo. Ins. Estud. Vigueses, pp. 111-152.

Fraga, F., 1981. Upwelling off the Galician coast, nothwest of Spain. In: Richards, F. (Ed.), Coastal Upwelling. American Geophysical Union, Washington, pp. 176-182.

González, H.E., Menschel, E., Aparicio, C., Barría, C., 2007. Spatial and termporal variability of microplankton and detritus, and their export to the shelf sediments in the upwelling area off Concepción, Chile ( 36오), during 20022005. Prog. Oceanogr. 75 (3): 435-451.

González, H.E., Daneri, G., Iriate, J.L., Yannicelli, B., Menschel, E., Barría, C., Pantoja, S., Lizárraga,L., 2009. Carbon fluxes within the epipelagic zone of the Humboldt Current System off Chile: The significance of euphausiids and diatoms as key functional groups for the biological pump. Prog. Oceanogr., 83 $(1-4): 217-227$. 
Hansen, H.P. and Grasshoff, K., 1983. Automated chemical analysis. In: Grasshoff, K., Ehrhadt, M., and Kremling, K. (Eds). Methods of seawater analysis. Verlag Chemie, Weinheim, p. 347-395.

Hargrave, B.T., Budgen, G.L., Head, E.J.H., Petrie, B., Phillips, G.A., Subba Rao, D.V., Yeats, P.A., 2007. Factors affecting seasonality of lithogenic and biogenic particle flux in a large stuarine ecosystem. Estuar. Coast. Shelf S. 73 : 379-398.

Head, E.J.H. and Harris, L.R., 1994. Feeding selectivity by copepods grazing on natural mixtures of phytoplankton determined by HPLC analysis of pigments. Mar. Ecol. Progr. Ser. 110: 75-84.

Herrera, L., Escribano, R., 2006. Factors structuring the phytoplankton community in the upwelling site off El Loa River in northern Chile. J. Marine Syst. 61: 13-38.

Hillebrand, H., Dürselen, C., Kirschtel, D., Pollingher, U., Zohary, T., 1999. Biovolume calculation for pelagic and benthic microalgae. Journal Phycologhy, 35: 403-424.

Kiorboe, T., Hansen, J.L.S., 1993. Phytoplankton aggregate formation: observations of patterns and mechanisms of cell sticking and the significance of exopolymeric material. J. Plank. Res., 15 (9): 993-1018.

Margalef, R., 1958. La sedimentación orgánica y la vida en los fondos fangosos de la ría de Vigo. Invest. Pesq. 11: 67-100.

Margalef, R., 1978. Life forms of phytoplankton as survival alternatives in an unstable environment. Ocean. Acta, 1: 493-509. 
Nogueira, E., Pérez, F.F., Ríos, A.F., 1997. Seasonal patterns and long-term trends in an estuarine upwelling ecosystem (Ria de Vigo, NW Spain). Estuar. Coast. Shelf S. 44 (3), 285-300.

Olli, K., Wexels Riser, C., Wassmann, P., Ratkova, T., Arashkevich, E., Pasternak, A., 2001. Vertical flux of biogenic matter during a Lagrangian study off the NW Spanish continental margin. Prog. Oceanogr. 51 (2-4): 443-466.

Pakhomov, E.A., Froneman, P.W., Wassmann, P., Ratkova, T., Arashkevich, E., 2002. Contribution of algal sinking and zooplankton to downward flux in the Lazarev Sea (Souther Ocean) during the onset of phytoplankton bloom: a lagrangian study. Mar. Ecol-Prog. Ser. 233: 73-88.

Passow, U. and Peinert, R., 1993. The role of plankton in particle flux: two case studies from the northeast Atlantic. Deep-Sea Res. 40 (1/2): 573-585.

Peinert, R., Bodungen, B.v., Smetacek V., 1989. Food web structure and loss rates. In: Berger, W.H., Smetacek, V.S. and Wefer, G. (Eds). Productivity of the oceans: present and past, Wiley, Chichester , pp. 35-48.

Pilskaln, C., Honjo, S., 1987. The fecal pellet fraction of biogeochemical particle fluxes to the deep sea. Global biogeochem Cy. 1: 31-48.

Pilskaln, C.H., Paduan, J.B., Chavez, F.P., Anderson, R.Y., Berelson, W., 1996. Carbon export and regeneration in the coastal upwelling system of Monterey Bay, central California. J. Mar. Res. 54: 1149-1178.

Pitcher, G.C., Walker, D.R., Mitchell-Innes, B.A., Moloney, C.L., 1991. Shortterm variability during an anchor station in the southern Benguela upwelling sysmtem: Phytoplankton dynamics. Prog. Oceanogr. 28: 39:64. 
Pommier, J., Michel, C., Gosselin, M., 2008. Particulate organic carbon export in the upper twilight zone during the decline of the spring bloom. Mar. EcolProg. Ser. 356: 81-92.

Putt, M., Stoecker, D.K., 1989. An experimentally determined carbon : volume ratio for marine "oligotrichous" ciliates from estuarine and coastal waters. Limn. Oceanogr., 34(6): 1097-1103.

Reigstad, M., Riser, C.W., Wassmann, P., Ratkova, T., 2008. Vertical export of particulate organic carbon: Attenuation, composition and loss rate in the northern Barents Sea. Deep-Sea Res. Pt. II, 55 (20-21): 2245-2256.

Sanchez, G.E., Pantoja, S., Lange, C.B., González, H.E., Daneri, G., 2008. Seasonal changes in particulate biogenic and lithogenic silica in the upwelling system off Concepción ( 36ํㅗ), Chile, and their relationship to fluxtuations in marine productivity and continental input. Cont. Shelf Res. 28: 2594-2600.

Strathmann, R., 1967. Estimating the organic carbon content of phytoplankton from cell volume or plasma volume. Limnology and Oceanography, 12:411-418.

Svensen, C., Vilicic, D., Wassmann, P., Arashkevich, E., Ratkova, T., 2007. Plankton distribution and vertical flux of biogenic matter during high summer stratification in the Krka estuary (Eastern Adriatic). Estuar. Coast. Shelf S. 71: 381-390.

Tamelander, T., Heiskanen, A.S., 2004. Effects of spring bloom phytoplankton dynamics and hydrography on the composition of settling material in the coastal northern Baltic Sea. J. Mar. Syst. 52: 217-234. 
Tilstone, G.H., Figueiras, F.G., Fermín, E.G., Arbones, B., 1999. Significance of nanophytoplankton photosynthesis and primary production in a coastal upwelling system (Ría de Vigo, NW Spain). Mar. Ecol-Prog. Ser. 183: 13-27.

Tilstone, G.H., Míguez, B.M., Figueiras, F.G., Fermín, E.G., 2000. Diatom dynamics in a coastal ecosystem affected by upwelling: coupling between species succession, circulation and biogeochemical processes. Mar. Ecol-Prog. Ser. 205: 23-41.

Thunell, R.C., 1998. Particle fluxes in a coastal upwelling zone: sediment trap results from Santa Barbara Basin, California. Deep-Sea Res. Pt. II, 45: 18631884.

Varela, M., Prego, R., Belzunce, M.J., Martín-Salas, F., 2001. Inshore-offshore differences in seasonal variations of phytoplankton assemblages: the case of a Galician Ria Alta (A Coruña Ría) and its adjacent shelf (NW Spain). Cont. Shelf Res. 21: 1815-1838.

Varela, M., Prego, R., Pazos, Y., 2004. Vertical biogenic particle flux in a western Galician ria (NW Iberian Peninsula). Mar. Ecol-Prog. Ser. 269: 17-32.

Verity, P.G., Robertson, C.Y., Tronzo, C.R., Andrews, M.G., Nelson, J.R., Sieracki, M.E., 1992. Relationships between cell volume and the carbon and nitrogen content of marine photosynthetic nanoplankton. Limnol. \& Ocenogr. 37. 7: 1434-1446.

Wassmann, P., 1991. Dynamics of primary production and sedimentation in shallow fjords and polls of Western Norway. Oceanogr. Mar. Biol. Annu. Rev. 29: 87-154. 
Wassmann, P., Svendsen, H., Keck, A., Reigstad, M., 1996. Selected aspects of the physical oceanography and particle fluxes in fjords of northern Norway. J. Mar. Syst. 8: 53-71.

Wassmann, P., Olli, K., Wexels Riser, C., Svensen, C., 2003. Ecosystem function, biodiversity and vertical flux regulation in the twilight zone. In: Wefer, G., Lamy, F. and Mantoura, F. (Eds), Marine Science Frontiers for Europe, Springer, Berlin, pp. 277-285.

\section{FIGURE CAPTIONS}

Figure 1. Location map of the Ría de Vigo showing the sampling stations (IR: inner Ría, OU: outside station).

Figure 2. Time-series of upwelling index $\left(\mathrm{m}^{3} \mathrm{~s}^{-1} \mathrm{~km}^{-1}\right)$, temperature and nitrate concentration recorded at the inner Ría (IR) sampling station. Summer stratification period described the oceanographic conditions registered at the OU station.

Figure 3. Time-series of water column chlorophyll-a (chl a) and particulate organic carbon (POC), phytoplankton abundance $\left(10^{6} \mathrm{cel} \mathrm{m}^{-3}\right)$ and biomass (mg $\mathrm{C} \mathrm{m}^{-3}$ ) registered at the inner Ría (IR) station. Data from summer stratification period correspond to the $\mathrm{OU}$ station. Broken lines in both spring and autumn periods mark the abrupt change in hydrographic conditions as reported in Figure 2.

Figure 4. Time-series of the main phytoplankton group biomasses: diatoms, dinoflagellates and flagellates (in terms of percentage). Broken lines in both 
spring and autumn periods mark the abrupt change in hydrographic conditions as reported in Figure 2.

Figure 5. Time-series of particulate organic carbon (POC), living phytoplankton carbon $\left(\mathrm{C}_{\text {phyto }}\right)$ and chlorophyll-a (chl a) fluxes. Bar plots showing the temporal evolution of the main phytoplankton groups recorded by the sediment traps expressed both in terms of abundance $\left(10^{6} \mathrm{cel} \mathrm{m}^{-2} \mathrm{~d}^{-1}\right)$ and biomass $\left(\mathrm{mg} \mathrm{C} \mathrm{m}^{-2}\right.$ $\left.d^{-1}\right)$.

Figure 6. Mean major phytoplankton species in the water column (up bars) and in sediment traps (down bars) in terms of (a) abundance (water column: $10^{6} \mathrm{cel}$ $\mathrm{m}^{-3}$; sediment trap: $10^{6} \mathrm{cel} \mathrm{m}^{-2} \mathrm{~d}^{-1}$ ) and (b) biomass (water column: $10^{-3} \mathrm{mg} \mathrm{m}^{-3}$; sediment trap: $10^{-3} \mathrm{mg} \mathrm{m}^{-2} \mathrm{~d}^{-1}$ ) for each sampling period. Additional cross line bars in spring and autumn were used to show variations between the different hydrographic conditions recorded during these periods, as reported in Figure 2. 
Table 1. Mean seasonal values ( \pm Standard Deviation) of biogeochemical properties in the water column. POC: Particulate Organic Carbon; $\mathrm{C}_{\text {phyto: }}$ living phytoplankton carbon; DCR: Dark Community Respiration; NCP: Net Community Production. Mean values of the biomass percentage for the main phytoplanktonic groups (Diatoms; Dino: dinoflagellates; Flag: flagellates) for each sampling season are also presented. Different hydrographic conditions (as shown in Figure 2) in spring (D: Downwelling and U:Upwelling) and autumn (U: Upwelling and M: Mixing) have been taken into account.

\begin{tabular}{|c|c|c|c|c|c|c|c|c|c|c|}
\hline & & $\begin{array}{c}\mathrm{POC} \\
m g m^{-2}\end{array}$ & $\begin{array}{c}\mathrm{C}_{\text {phyto }} \\
m g m^{-2}\end{array}$ & $\begin{array}{c}\% \mathrm{C}_{\text {phyto }} / \mathrm{POC} \\
m g: m g\end{array}$ & $\begin{array}{c}\mathrm{C} / \mathrm{N} \\
\text { atomic:atomic }\end{array}$ & $\begin{array}{c}\text { DCR } \\
m m o l m^{-2} d^{1}\end{array}$ & $\begin{array}{c}\mathrm{NCP} \\
m m o l m^{-2} d^{1}\end{array}$ & \%Diatoms & \% Dino & $\%$ Flag \\
\hline \multirow[t]{2}{*}{ Spring } & D & $3318 \pm 416$ & $3648 \pm 952$ & $109 \pm 15$ & $5.5 \pm 0.9$ & $115 \pm 4$ & $38 \pm 22$ & $40 \pm 24$ & $4 \pm 1$ & $50 \pm 23$ \\
\hline & $U$ & $3157 \pm 885$ & $5574 \pm 4441$ & $163 \pm 95$ & $7.0 \pm 0.8$ & $94 \pm 101$ & $154 \pm 7$ & $70 \pm 31$ & $3 \pm 2$ & $25 \pm 29$ \\
\hline $\begin{array}{l}\text { Summer } \\
\text { upwelling }\end{array}$ & & $5225 \pm 1452$ & $3982 \pm 1724$ & $74 \pm 24$ & $8.2 \pm 2.3$ & $75 \pm 27$ & $406 \pm 99$ & $94 \pm 3$ & $4 \pm 1$ & $1 \pm 0$ \\
\hline $\begin{array}{l}\text { Summer } \\
\text { stratification }\end{array}$ & & $3205 \pm 382$ & $971 \pm 668$ & $29 \pm 16$ & $7.2 \pm 1.8$ & $75 \pm 60$ & $149 \pm 17$ & $61 \pm 38$ & $15 \pm 8$ & $8 \pm 14$ \\
\hline \multirow[t]{2}{*}{ Autumn } & $U$ & $3582 \pm 1269$ & $2078 \pm 1329$ & $52 \pm 36$ & $4.8 \pm 0.3$ & $67 \pm 29$ & $106 \pm 100$ & $81 \pm 11$ & $18 \pm 12$ & $0 \pm 0$ \\
\hline & M & $1963 \pm 13$ & $420 \pm 204$ & $21 \pm 11$ & $6.9 \pm 0.5$ & $34 \pm 4$ & $-13 \pm 15$ & $59 \pm 11$ & $39 \pm 12$ & $1 \pm 1$ \\
\hline Winter & & $1947 \pm 348$ & $45 \pm 8$ & $2 \pm 1$ & $7.1 \pm 1.5$ & $30 \pm 17$ & $22 \pm 16$ & $42 \pm 18$ & $36 \pm 22$ & $20 \pm 8$ \\
\hline
\end{tabular}


Table 2. Mean seasonal values ( \pm Standard Deviation) of biogeochemical properties from sediment traps samples. POC: Particulate Organic Carbon; $\mathrm{C}_{\text {phyto }}$ : living phytoplankton carbon. Mean values of the biomass for the main phytoplanktonic groups (Diatoms; Dino: dinoflagellates; Flag: flagellates) for each sampling season are also presented in the table. Different hydrographic conditions (as shown in Figure 2) in spring (D: Downwelling and U:Upwelling) and autumn (U: Upwelling and M: Mixing) have been taken into account in order to give mean values for the different variables presented in the table.

\begin{tabular}{|c|c|c|c|c|c|c|c|c|c|c|c|}
\hline & & $\begin{array}{c}\text { POC } \\
m g m^{-2} d^{1}\end{array}$ & $\begin{array}{c}\mathrm{C}_{\text {phyto }} \\
m g m^{-2} d^{-1}\end{array}$ & $\begin{array}{c}\% \mathrm{C}_{\text {phyto }} / \mathrm{POC} \\
m g: m g\end{array}$ & $\begin{array}{c}\mathrm{C} / \mathrm{N} \\
\text { atomic:ato } \\
\text { mic }\end{array}$ & $\begin{array}{c}\text { Chl } a \\
m g m^{-2} d^{1}\end{array}$ & $\begin{array}{c}\mathrm{C}_{\text {phyto }} / \mathrm{Chl} a \\
m g: m g\end{array}$ & $\begin{array}{c}\text { phaeo/Chl a } \\
m g: m g\end{array}$ & \%Diatoms & \%Dino & \%Flag \\
\hline \multirow[t]{2}{*}{ Spring } & $\mathrm{D}$ & $1239 \pm 80$ & & & $6.2 \pm 0.7$ & & & & & & \\
\hline & $U$ & $688 \pm 144$ & & & $6.4 \pm 2.2$ & & & & & & \\
\hline $\begin{array}{l}\text { Summer } \\
\text { upwelling }\end{array}$ & & $1123 \pm 432$ & $260 \pm 219$ & $26 \pm 19$ & $6.8 \pm 2.0$ & $16 \pm 5$ & $15 \pm 9$ & $1.7 \pm 0.6$ & $96 \pm 5$ & $4 \pm 3$ & $3 \pm 5$ \\
\hline $\begin{array}{l}\text { Summer } \\
\text { stratification }\end{array}$ & & $968 \pm 272$ & $198 \pm 201$ & $18 \pm 14$ & $6.9 \pm 0.2$ & $8 \pm 4$ & $21 \pm 11$ & $2.4 \pm 1.2$ & $79 \pm 10$ & $16 \pm 8$ & $1 \pm 1$ \\
\hline \multirow[t]{2}{*}{ Autumn } & $U$ & $760 \pm 125$ & $139 \pm 51$ & $18 \pm 4$ & $5.8 \pm 0.7$ & $9 \pm 5$ & $16 \pm 4$ & $1.2 \pm 0.2$ & $83 \pm 17$ & $3 \pm 3$ & $0 \pm 0$ \\
\hline & M & $1347 \pm 272$ & $51 \pm 3$ & $4 \pm 1$ & $7.1 \pm 0.9$ & $5 \pm 3$ & $15 \pm 11$ & $2.1 \pm 0.7$ & $84 \pm 18$ & $12 \pm 13$ & $4 \pm 4$ \\
\hline Winter & & $1319 \pm 462$ & $28 \pm 6$ & $2 \pm 1$ & $11.5 \pm 3.0$ & $0.8 \pm 0.6$ & $119 \pm 172$ & $7.0 \pm 5.5$ & $82 \pm 10$ & $12 \pm 12$ & $6 \pm 3$ \\
\hline
\end{tabular}




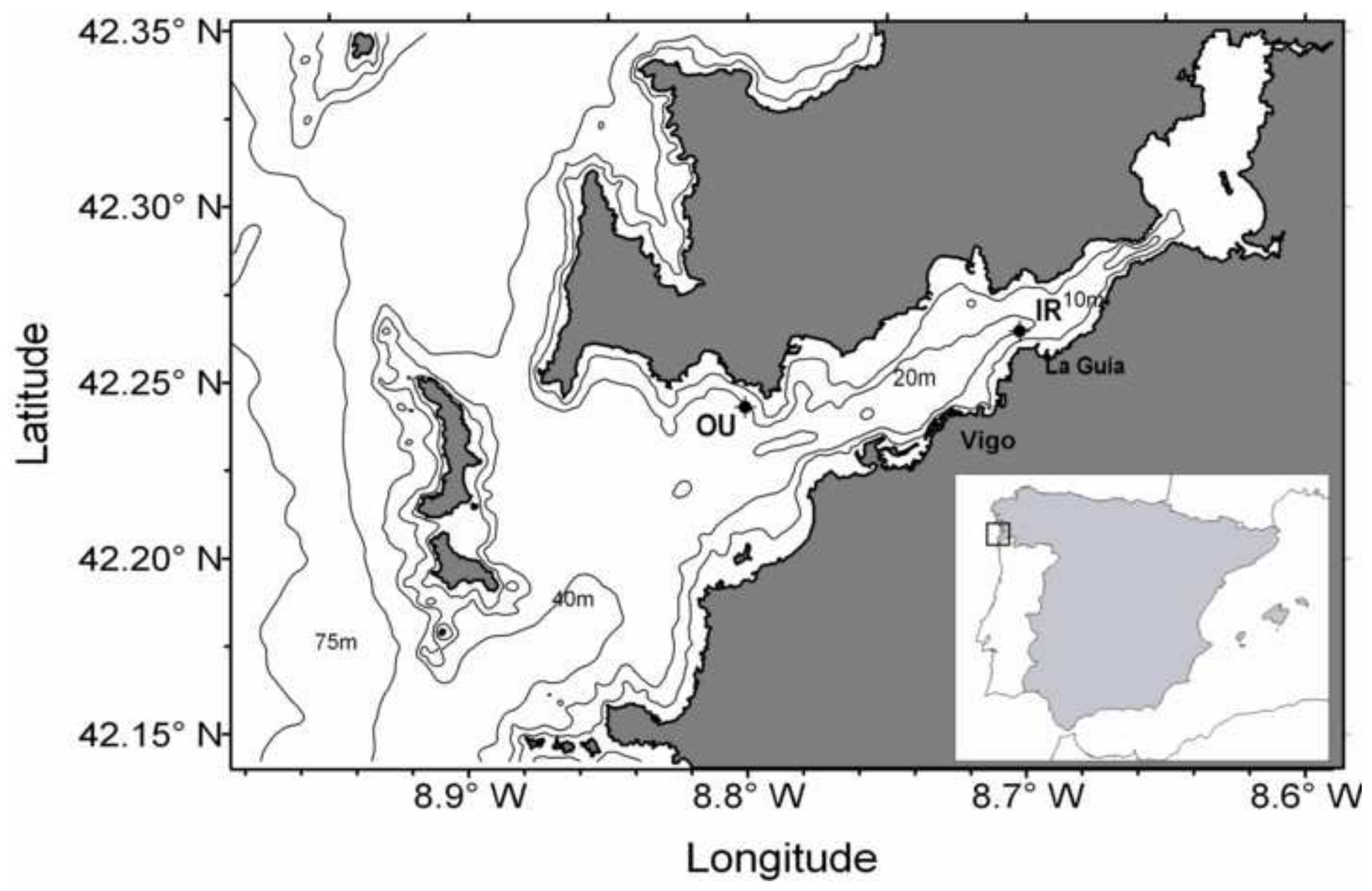



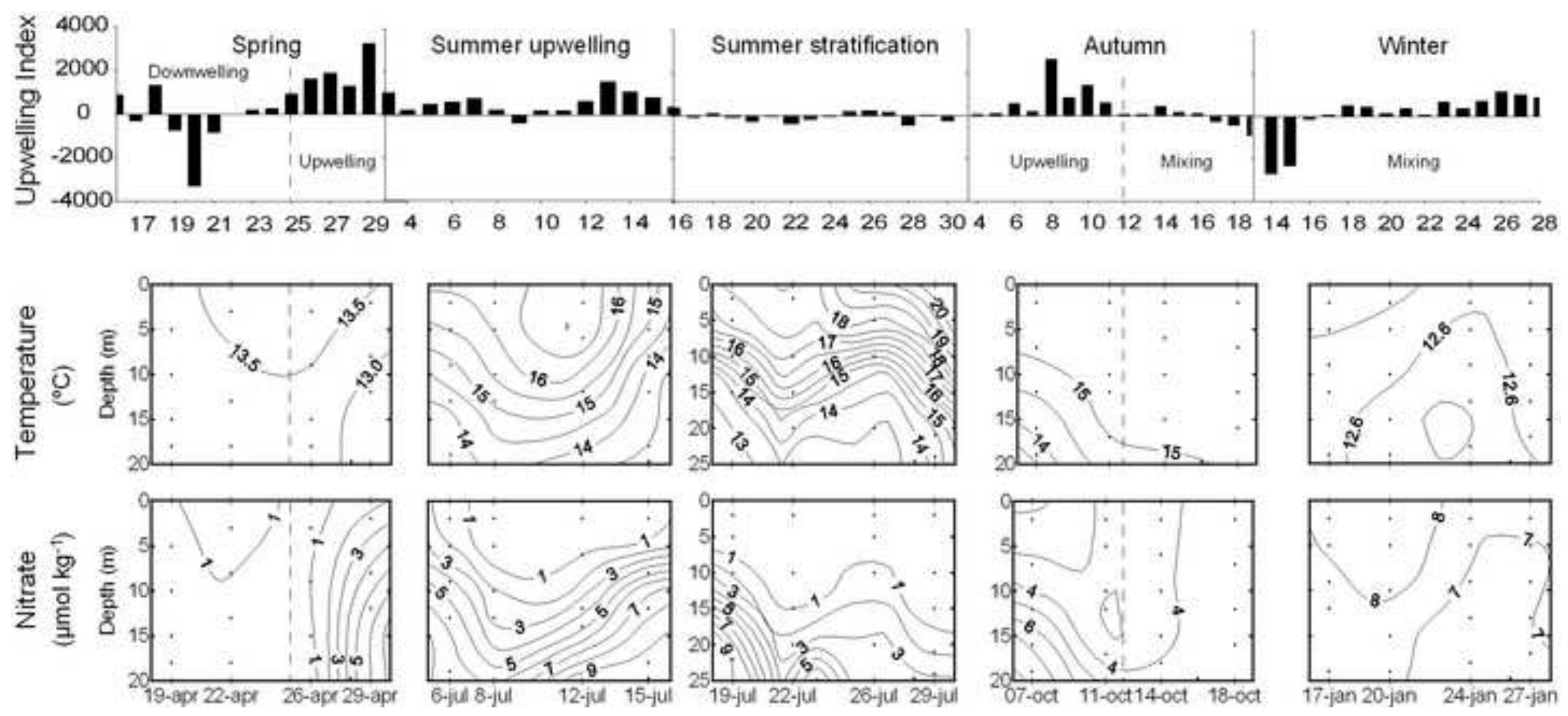


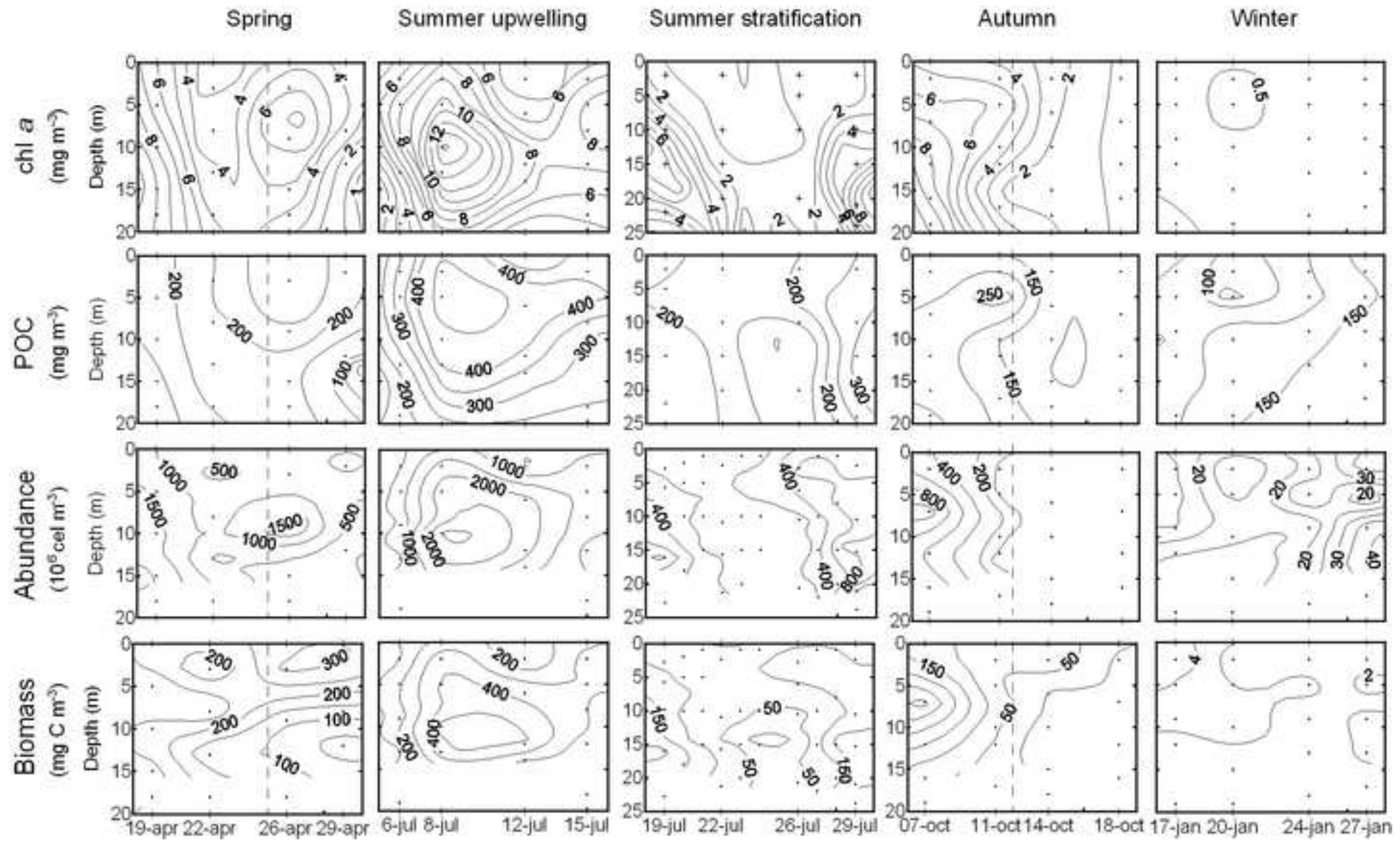




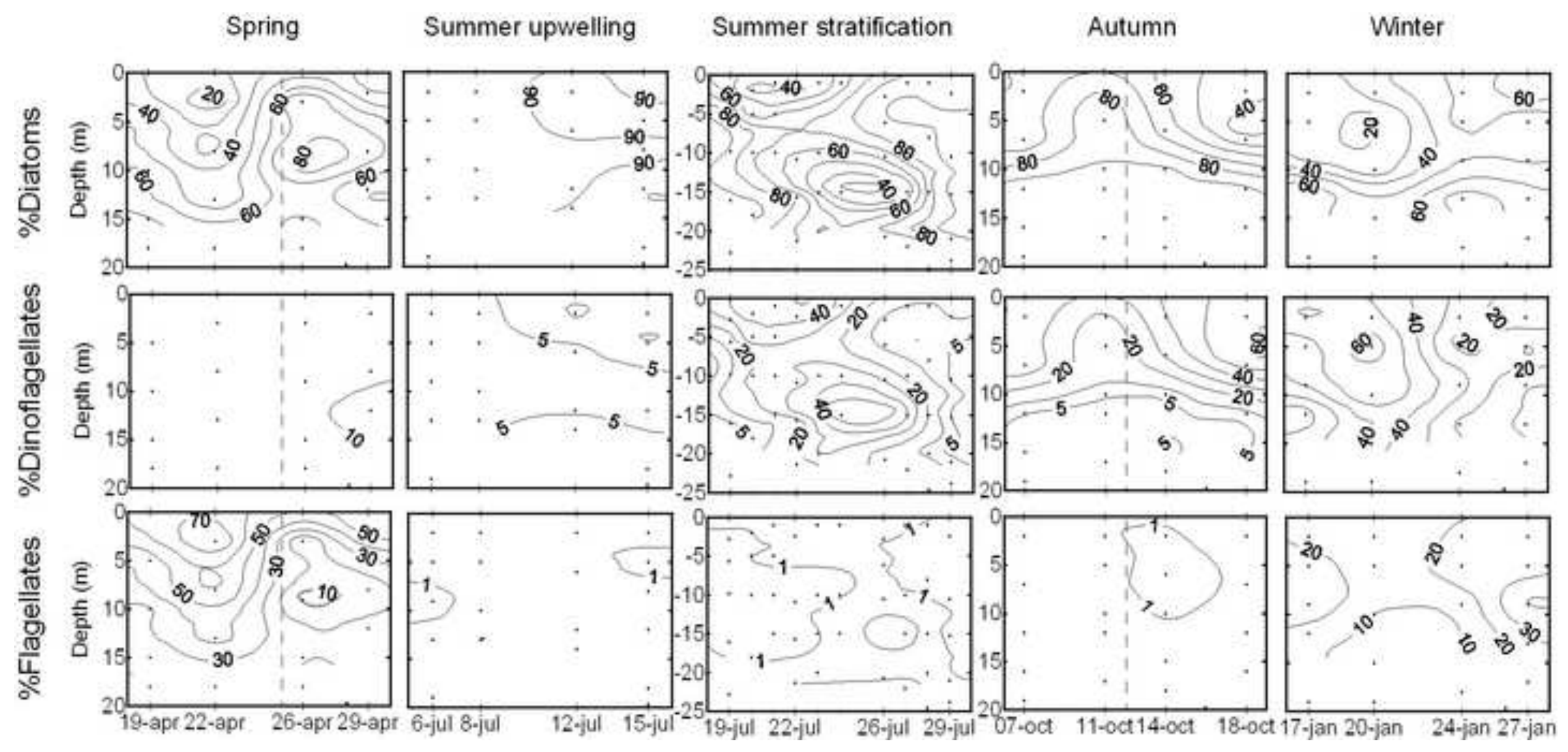




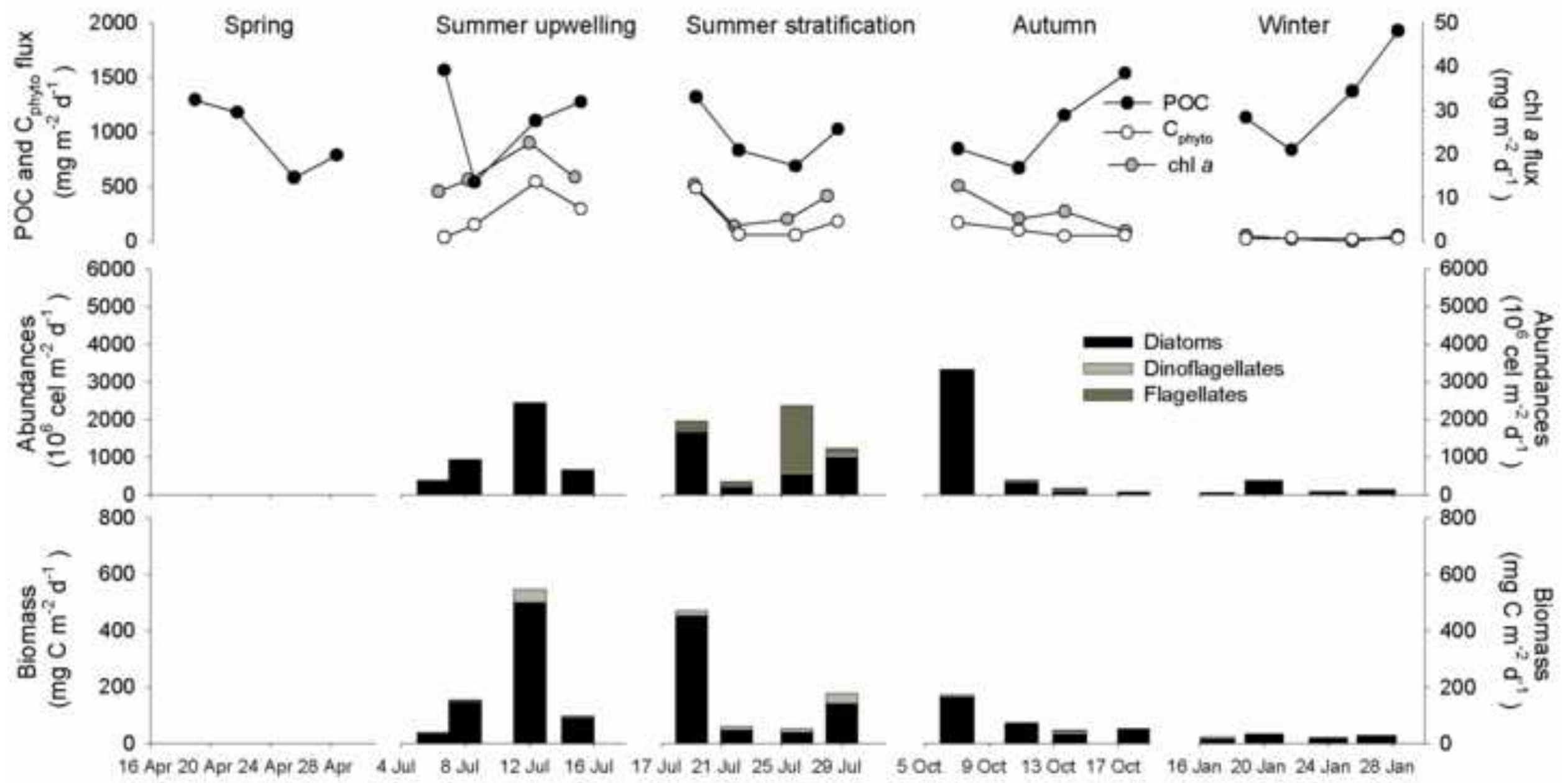



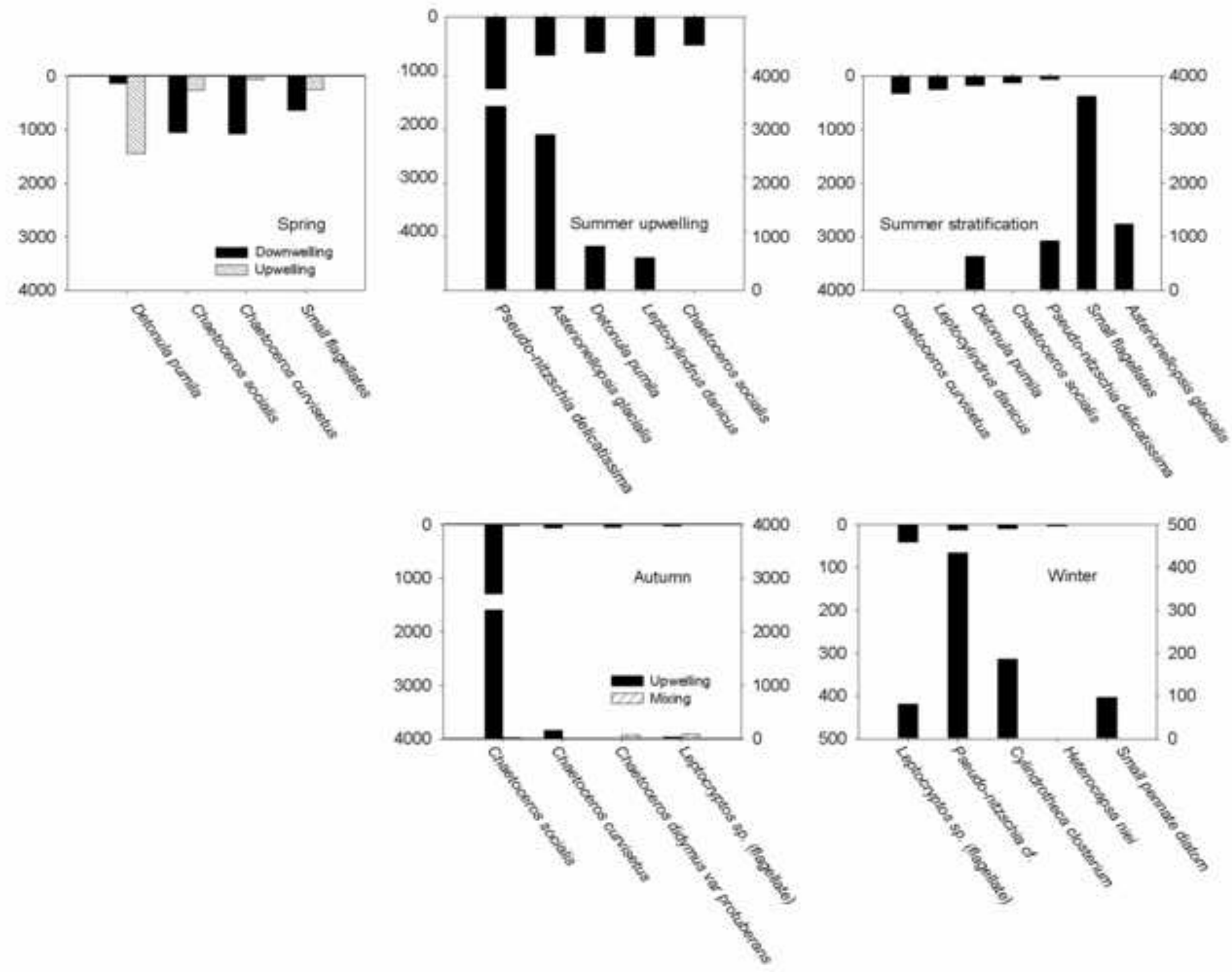


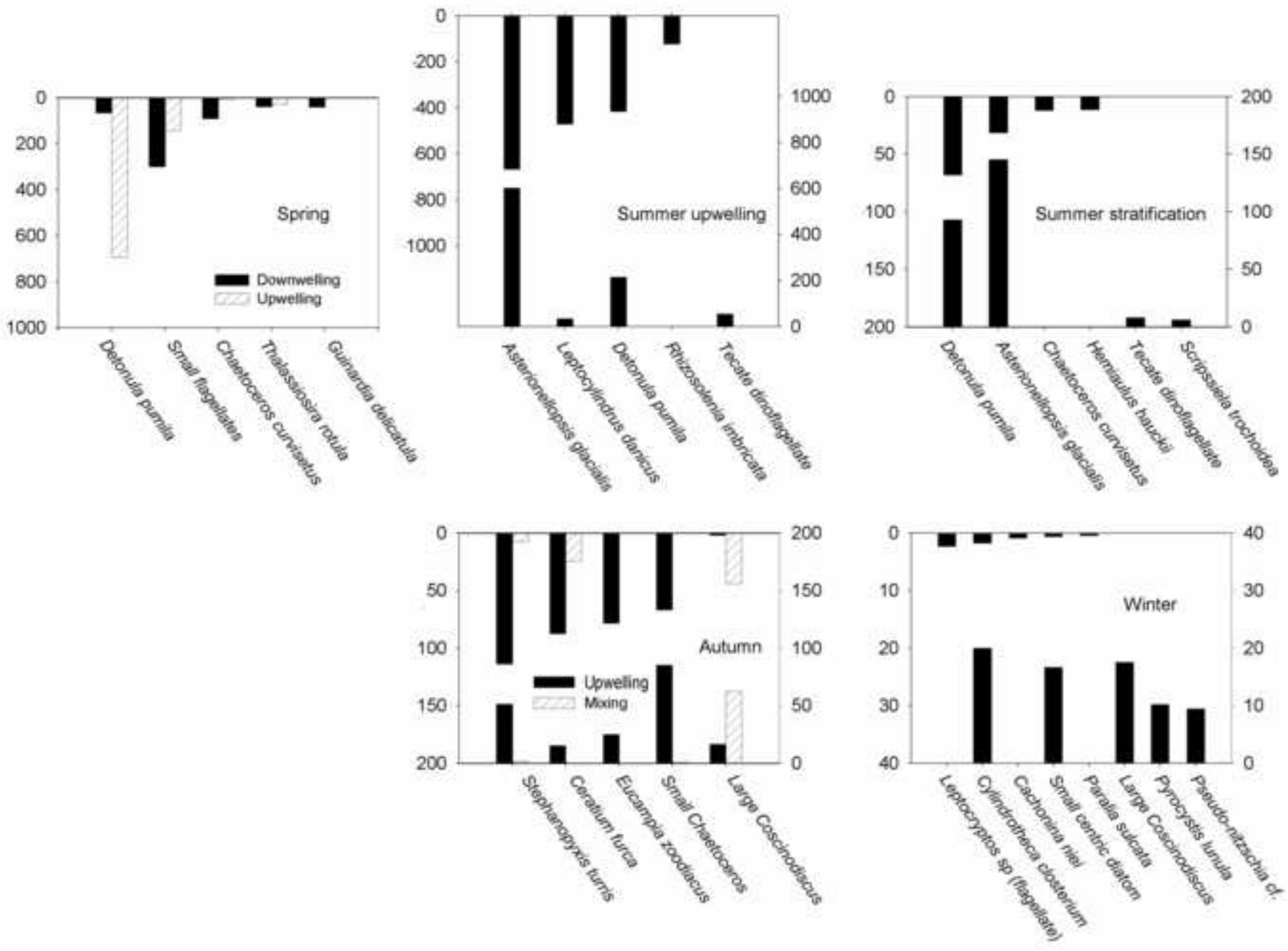

